\title{
Pengenalan Penelitian Tindakan Kelas (PTK) Bagi Guru-Guru Sekolah SMP Muhammadiyah Rawalo, Kabupaten Banyumas
}

\author{
Listiani $^{1}$, Bambang Suroso ${ }^{2}$ \\ ${ }^{1.2}$ Universitas Muhammadiyah Purwokerto \\ Email: ${ }^{1}$ listiani@ump.ac.id
}

\begin{abstract}
Abstrak
Pengabdian bagi masyarakat ini mengambil topik "Pengenalan Penelitian Tindakan Kelas (PTK)." Tujuan Pengabdian ini adalah untuk mengenalkan metodologi penelitian pada umumnya dan PTK terkait tujuan, fungsi, karakteristik dan desain sehingga para guru SMP Muhammadiyah Rawalo, kabupaten Banyumas, Jawa Tengah, Indonesia memiliki pengetahuan dan kesadaran untuk meneliti dan meningkatkan kualitas pembelajaran. Kegiatan pengabdian ini dilakukan pada hari Senin,7 Januari 2019 dan ada 18 orang guru yang bergabung. Metode yang diterapkan dalam kegiatan pengabdian ini adalah penyuluhan dan diskusi. Hasil dari kegiatan ini adalah para guru bisa menentukan permasalahan pembelajaran yang bisa diangkat menjadi permasalahan PTK, bisa menyebutkan langkah-langkah ilmiah dalam PTK dan termotivasi untuk melakukan penelitian PTK. Dari kegiatan pengabdian ini dapat disimpulkan bahwa kegiatan ini mampu mengenalkan dan memberikan pengetahuan dan keterampilan tentang metodologi penelitian pada umumnya dan pengetahuan tentang PTK dengan baik dan mitra juga mengharapkan kegiatan pengabdian yang lainnya di masa datang.
\end{abstract}

Kata Kunci: landasan penelitian, metodologi penelitian, PTK

\begin{abstract}
This community service took a topic "Introducing classroom action research (CAR)." This service was for introducing research methodology in general and CAR for its function, characteristics, and design, so the teachers of SMP Muhammadiyah Rawalo, Banyumas district. Central Java Province, Indonesia could get research knowledge and improve their awareness towards research and learning. This community service program was conducted on Monday, $7^{\text {th }}$ of January 2019 and there were eighteen (18) secondary school teachers who joined in it. The method of this community service was counseling and discussion. The result of this activity was that the teachers could identify learning problem as CAR's topic, mention scientific steps taken for CAR, and be motivated to do CAR. In conclusion, this community service was able to introduce and give knowledge and skills on research methodology in general and CAR well, and the participants expected another community service program conducted in the future.
\end{abstract}

Keywords: research foundation, research methodology, CAR design

\section{PENDAHULUAN}

Mengenal penelitian adalah langkah awal guru untuk mengembangkan kualitas diri menuju guru yang profesional. Guru menjadi tahu tentang apa penelitian itu dan mengapa penelitian dilakukan. Dengan mengetahui hal tersebut, minat guru tumbuh dan memiliki alasan yang kuat untuk memahami dan menerapkan penelitian.Salah satu jenis penelitian yang perlu mendapat perhatian guru dan yang perlu guru kenal adalah Penelitian Tindakan Kelas (PTK).PTK berupaya meningkatkan dan mengembangkan profesionalisme guru dalam menunaikan tugasnya (Drs. H. Mahmud, M. Si dan Tedi Priatna, 2008). 
Penelitian Tindakan Kelas ini dilaksanakan berdasarkan masalah pembelajaran yang ditemui di dalam kelas. Penelitian Tindakan Kelas (PTK) merupakan suatu bentuk penelitian yang bersifat reflektif dengan melakukan tindakan-tindakan tertentu agar dapat memperbaiki atau meningkatkan praktik-praktik pembelajaran di kelas secara lebih profesional (Suyanto, 1997: 4 dalam Drs. H. Mahmud, M. Si dan Tedi Priatna, 2008). Dengan penelitian tersebut, guru mengidentifikasi permasalahan utama di proses pembelajaran, melakukan upaya perbaikan permasalahan yang ditemui, dan melakukan upaya peningkatan kualitas pembelajaran dengan menggunakan langkahlangkah ilmiah. Dengan mengikutsertakan teman sejawat dibidang yang sama yang merupakan ciri khas jenis penelitian ini akan meningkatkan kepedulian terhadap kualitas pembelajaran dan antar sesama kolega. Mereka merancang, melaksanakan dan merefleksikan tindakan secara kolaboratif dan partisipatif.

Melalui penelitian PTK, guru bertindak secara ilmiah dalam memperbaiki permasalahan di kelas. Meski tanpa kita pungkiri bahwa guru telah melakukan segala upaya agar pembelajaran di kelas lebih baik. Mereka terus menerapkan dan memperbaharui beragam teknik, media, bahkan rancangan pembelajaran, namun usaha mereka hanya sebatas itu saja. Mereka tidak melakukan kegiatan tersebut secara sistematis dan hasilnya tidak dijadikan referensi atau pengetahuan yang bisa ditularkan kepada pendidik yang lain.

Keterbatasan upaya guru dalam memperbaiki permasalahan pembelajaran di kelas merupakan bentuk kurang mengenalnya mereka dengan penelitian. Mereka belum peduli akan pentingnya penerapan langkah-langkah ilmiah dalam aktifitas-aktifitas penyelesaian masalah di kelas mereka. Mereka juga tidak memahami bahwa kegiatan perbaikan tersebut bisa menjadi bahan refleksi pembelajaran yang dapat dipertanggungjawabkan bagi dirinya maupun bagi orang lain.

Guru-guru di SMP Muhammadiyah di Rawalo tidak sepenuhnya mengenal Penelitian Tindakan Kelas. Meski mereka pernah menyelami bangku perkuliahan, pengetahuan akan penelitian dan minat meneliti semakin berkurang karena kesibukan dari aktivitas rutin sebagai guru. Dengan mengenalkan PTK kembali dan memupuk pengetahuan tersebut, diharapkan para guru memiliki minat dan motivasi untuk menerapkan langkah-langkah ilmiah dalam perbaikan permasalahan pembelajaran di kelas-kelas mereka sehingga mereka menjadi guru yang profesional.

Pengembangan minat, motivasi dan pemahaman guru-guru SMP Muhammadiyah di Rawalo akan penelitian tindakan kelas (PTK) perlu dilakukan. Dari hasil wawancara dengan Kepala Sekolah SMP Muhammadiyah di Rawalo, pengenalan PTK sangat penting diberikan bagi guruguru di sekolah tersebut karena sebagian besar guru adalah guru-guru yang masih muda dan perlu 
diberi motivasi dengan cara mengenalkan, membuat mereka paham dan membuat mereka memiliki kemampuan dalam meneliti.

Berdasarkan hasil wawancara tidak terstruktur tersebut, kegiatan pelatihan ini sangat perlu dilakukan untuk membantu para guru tersebut agar lebih mengenal dan memahami PTK. Pemberian bekal pengetahuan tentang definisi PTK, tujuan dan fungsi PTK, karakteristik PTK, dan desain PTK, perlu diberikan sehingga diharapkan mereka termotivasi untuk melakukan penelitian tersebut.

Pengabdian bagi masyarakat ini bertujuan untuk memberi kesadaran untuk meneliti dan melakukan usaha peningkatan kualitas pembelajaran melalui penelitian, memberi pengetahuan tentang PTK dan manfaatnya, mengoptimalkan kemampuan guru dalam memahami PTK dan sekaligus membekali para guru tentang pengetahuan definisi PTK, tujuan dan fungsi PTK, karakteristik PTK, dan desain PTK sebagai bekal guru melakukan penelitian PTK.

Dengan tercapainya tujuan tersebut, guru memiliki kesadaran untuk meneliti dan melakukan usaha peningkatan kualitas pembelajaran melalui penelitian, memiliki pengetahuan tentang PTK dan manfaatnya, memiliki kemampuan yang optimal dalam memahami PTK dan mengetahui tentang pengetahuan definisi PTK, tujuan dan fungsi PTK, karakteristik PTK, dan desain PTK sebagai bekal guru melakukan penelitian PTK.

\section{METODE}

Program penerapan ipteks bagi masyarakat ini dilaksanakan dengan metode penyuluhan.. Kegiatan ABDIMAS ini diperuntukan bagi para guru SMP Muhammadiyah Rawalo di kecamatan Rawalo, Kabupaten Banyumas, provinsi Jawa Tengah, Indonesia. Penyuluhan ini dilaksanakan pada hari Senin, 7 Januari 2019 dengan mempertimbangkan fasilitas pendukung kegiatan, keleluasaan tempat untuk praktik para peserta pelatihan, lokasi yang strategis, keleluasaan waktu dan kegiatan baik peserta maupun pemateri, dan keterbatasan waktu, tenaga dan pikiran para peserta.

\section{HASIL DAN DISKUSI}

Kegiatan pengabdian bagi masyarakat ini dilaksanakan dalam bentuk penyuluhan untuk mengenalkan penelitian tindakan kelas (PTK). Kegiatan ini diperuntukan bagi guru-guru SMP Muhammadiyah Rawalo kecamatan rawalo, kabupaten Banyumas yang dilaksanakan pada Senin, 7 Januari 2019. Sejumlah 18 guru di sekolah tersebut ikut serta dalam kegiatan tersebut.

Dari kegiatan pengabdian yang dilaksanakan, para guru mendapatkan pengetahuan dan pemahaman tentang penelitian tindakan kelas dan mereka juga mendapatkan bekal untuk 
meningkatkan profesionalitas berkelanjutan. Kegiatan pengenalan ini dilakukan melalui kegiatan pemaparan materi, sesi tanya jawab dan studi kasus. Hasil yang diperoleh dari kegiatan ini adalah para guru bisa menentukan permasalahan pembelajaran yang bisa diangkat menjadi permasalahan PTK, bisa menyebutkan langkah-langkah ilmiah dalam PTK dan termotivasi untuk melakukan penelitian PTK.

Implementasi pelatihan ini dilaksanakan melalui 5 (lima) tahapan. Pertama, pada awal pelatihan, guru diberikan motivasi untuk mengembangkan profesionalisme mereka melalui penerapan budaya meneliti. Tahapan kedua yaitu guru dikenalkan tentang definisi PTK, tujuan dan fungsi PTK, karakteristik PTK, dan desain PTK. Ketiga, guru dilatih untuk mengaitkan pengetahuan di tahap kedua dengan permasalahan pembelajaran di kelas yang bisa diangkat menjadi topic PTK. Para guru mengidentifikasi permasalahan pembelajaran di kelas, merencanakan penelitian PTK, dan menyusun alur penelitian. Keempat, penyaji dan para guru melakukan review terhadap hasil pekerjaan antar kolega dan menarik kesimpulan. Kelima, penyaji dan peserta bersama-sama mereview kegiatan pelatihan. Para guru pada tahap ini menyampaikan tanggapan terhadap pelaksanaan pelatihan. Pada tahap ini juga, pelaksana dan mitra merencanakan kegiatan pengabdian lanjutan sebagai tindak lanjut kegiatan IbM kali ini.

\section{KESIMPULAN DAN SARAN}

Dari pembahasan diatas dapat ditarik kesimpulan bahwa kegiatan ipteks bagi masyarakat (IbM) yang berjudul "Pengembangan Profesionalisme Guru melalui Pengenalan Penelitian Tindakan Kelas bagi Guru-Guru SMP Muhammadiyah di Rawalo, kecamatan Rawalo, kabupaten Banyumas disambut baik dan berjalan dengan baik. Kegiatan ini mampu mengenalkan dan memberikan pengetahuan dan keterampilan tentang metodologi penelitian pada umumnya dan pengetahuan tentang PTK dengan baik dan para guru juga mengharapkan tindak lanjut kegiatan pengabdian ini di masa datang.

Guna mendukung suksesnya kegiatan serupa pada waktu-waktu mendatang dan kemanfaatan kegiatan yang telah dilaksanakan, perlu disediakan beberapa referensi pendukung kegiatan atau link internet yang menyediakan referensi terkait, dan perlu ditingkatkan frekuensi kegiatan serupa yang dilakukan secara rutin sehingga para pengajar memperoleh pengetahuan lebih dan dapat mengembangkan pengetahuan tersebut dalam bentuk karya ilmiah.

\section{UCAPAN TERIMAKASIH}

Pengabdian Masyarakat ini telah terlaksana dengan baik berkat kerjasama dari semua pihak yang terkait. Kami ucapkan banyak terimakasih kepada 1) Universitas Muhammadiyah 
Purwokerto yang telah mendukung dan membantu pendanaan kegiatan ini sehingga kegiatan ini berjalan dengan lancar, 2) LPPM Universitas Muhammadiyah Purwokerto yang telah mendukung kegiatan ini, 3) Sekolah Menengah Pertama Muhammadiyah Rawalo dan para staf guru yang telah memberikan kesempatan kerjasama dan izin untuk melaksanakan kegiatan ini, dan 4) rekan tim abdimas yang telah saling menguatkan sehingga kegiatan ini terlaksana dengan baik.

\section{REFERENSI}

Drs. H. Mahmud, M. Si dan Tedi Priatna, M. A. (2008). Penelitian Tindakan Kelas: Teori dan Praktik. Bandung: Tsabita. 
Lampiran Foto Pelaksanaan Abdimas

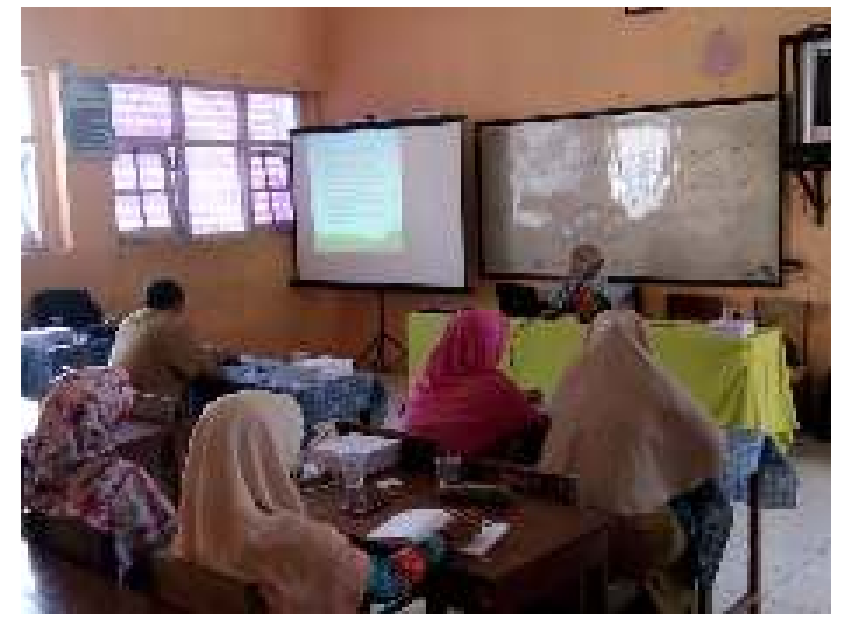

Gambar 1 Penyampaian Materi 1

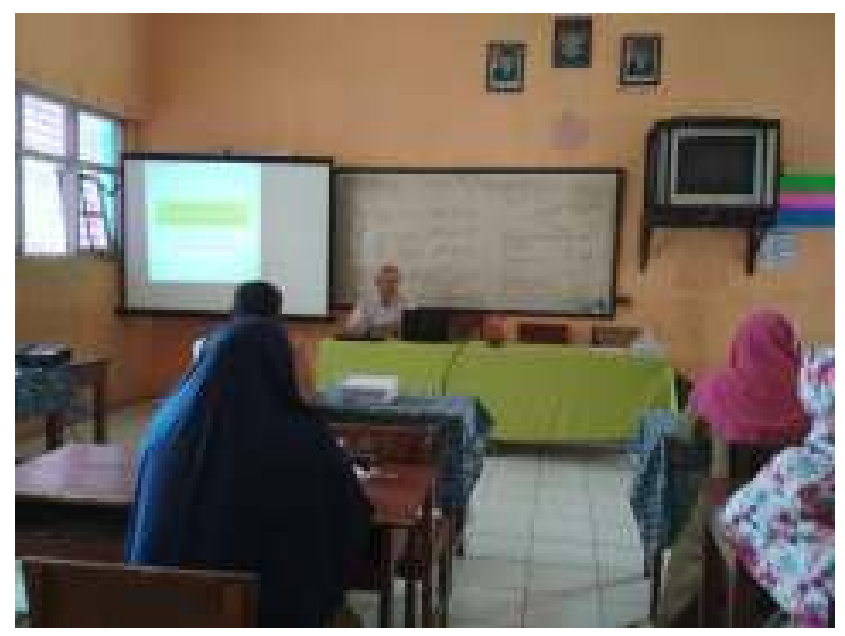

Gambar 2. Penyampaian Materi 2

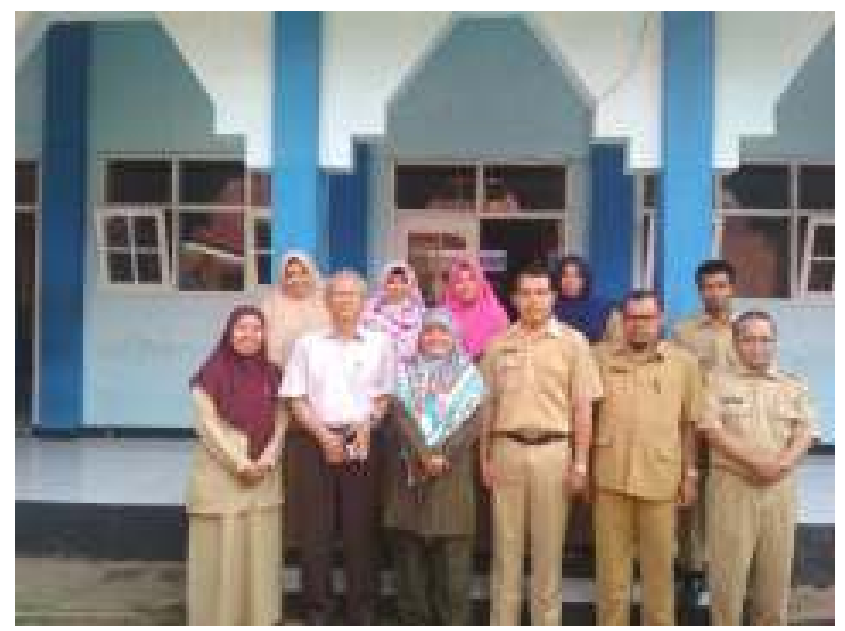

Gambar 3. Di Akhir Kegiatan 